\title{
AN ISLAMIC NUMERICAL INTERPRETATION OF HAGIA SOPHIA AT CONSTANTINOPLE
}

\author{
A B S S T R A C T
}

Ideas regarding aesthetical thinking on architecture developed through history a number of interpretations addressing its cultural and social importance. These interpretations appear as formations of possible worlds of meanings, structured through human power of imagination and reaching impressive levels of creative comprehension what architectural structure can reflect by its meaningful essence.

The paper explores one of such possible world of meanings, given in a form of numerical interpretation of the architectural structure of Hagia Sophia in Constantinople. Beside its complex and hermeneutic nature, the analyzed document reveals a highly sophisticated level of interactions of various cultural elements. They are composed into a whole which idealistic and poetic nature seems to be based on cosmopolitan approach to philosophy, religion, and human capability to comprehend the divine essence of creativity. It reminds us on the very nature of the intercultural nature of philosophic interpretation of architecture as a living condition of aesthetic thinking. Moreover, the document discussed in this paper, shows that such a fascination with architecture is not exclusive to the contemporary aesthetic thought, but represents one of the historical fundaments of that what social and cultural comunication in architecture is.

\section{Vladimir Mako}

University of Belgrade - Faculty of Architecture

ARCHITECTURE

NUMBER

SYMBOLISM

ISLAMIC PHILOSOPHY

COSMIC STRUCTURE 
Philosophical and theological interpretations of buildings are not an unusual occurrence in the history of architecture. Such expressions, however, often remain little more than identifying a given architectural object as an important cultural or religious artifact of an epoch, and by certain means their significance can be magnified to the symbolic level of the cosmic order and universal divine creative laws. One such building is without doubt the church of Hagia Sophia in Constantinople. In this article we will analyze a document representing this most important building of the Byzantine epoch. The document comprises drawings of the plan, section, axonometric section, and four details, namely the window, capital, a part of decoration, and the representation of a sphere. It has been found more than ten years ago among old books on architecture from the nineteenth century in Varna, Bulgaria, not as an integral part of any volume but as a separate page. Obviously, being a hand drawing, it has been purchased separately at some time and added to the collection of books (Figure 1).

The drawings were composed to produce a harmonious whole and framed with three rows of lines. A system of numbers corresponds to each image, related to the parts of the building. Two inscriptions can be seen within the composition: one, taking the central part above the drawings and presented on a ribbon, and the second, in the right lower corner. In the margins, on the left part of the document, but outside it, there are three inscriptions in Arabic letters. In the middle section above the lower margin we see a stamped library seal. The representation on the seal shows a central dome, with two minarets and two stars in the foreground.

The date and origin of the document are uncertain, mostly because there are religiously opposed elements in the representation of the building. The drawings present Hagia Sophia as it was built in Byzantine time, without any Islamic alterations. There is a cross placed on the top of the dome, in the section and axonometric presentation. The axonometric presentation of the interior emphasizes a cherub in the pendentive, as the cube placed on the spot where the Byzantine Emperors stood, and from which the Koran has been read in the Islamic era.

However, the Arabic inscriptions in the margins are comments related to the use of verses and terms related to the beginning of readings of Koranic chapters. They read: "regarding the pronouncement of "In the name of Allah the Merciful and all-Compassionate", when two intend to read the Koran... It is allowed, as it is allowed for them to speak "Praise be to Allah";' and '... and he answered that this cannot be pronounced. There is a question: is this a complete "ayah" 
or not, and is it regulated as a primal obligation from Allah - most Exalted. And because of this perplexity it should not be admitted in reading or handing down. These words also testify, that they speak how "tasmiya" distinguish from "ta'awwuza", considering to be an integral part of the Koranic text.' The nature of these texts refers to the possibility that the pictorial representation of the Hagia Sophia within the margins, and the related numerical system, can be thought as an important theological discussion.

The two inscriptions in the margins contribute to the uncertainty of the document's origin. They are not written according to the rules of Arabic calligraphy, and they are still not deciphered, although it is certain they are not in Persian, Turkish or Arabic. It is possible that the author of the document deliberately invented a kind of hermeneutic script, hiding its origin. Moreover, the first half of the inscription in the lower right corner, repeats the characters placed on the ribbon above the pictorial composition. This fact shows the existence of a logical matrix which binds these two inscriptions, probably containing the title and other information related to the document.

The Christian character of the way in which the Hagia Sophia is presented, as the Koranic comments in the margins point out, raise a few important issues, regarding the possible origins of these drawings. If the document originated within a Christian community and from a Christian author, before or after the conquest of Constantinople, certainly the comments on Koranic issues would not have originally been inscribed in the margins. This possibility allowed that even existing Muslim alterations to the building could be neglected in the presentation, which was an ongoing practice in some Christian drawings of Constantinople from the fifteenth century. ${ }^{1}$ However, in that case, the hermeneutic inscriptions accompanying the drawings could be explained as a

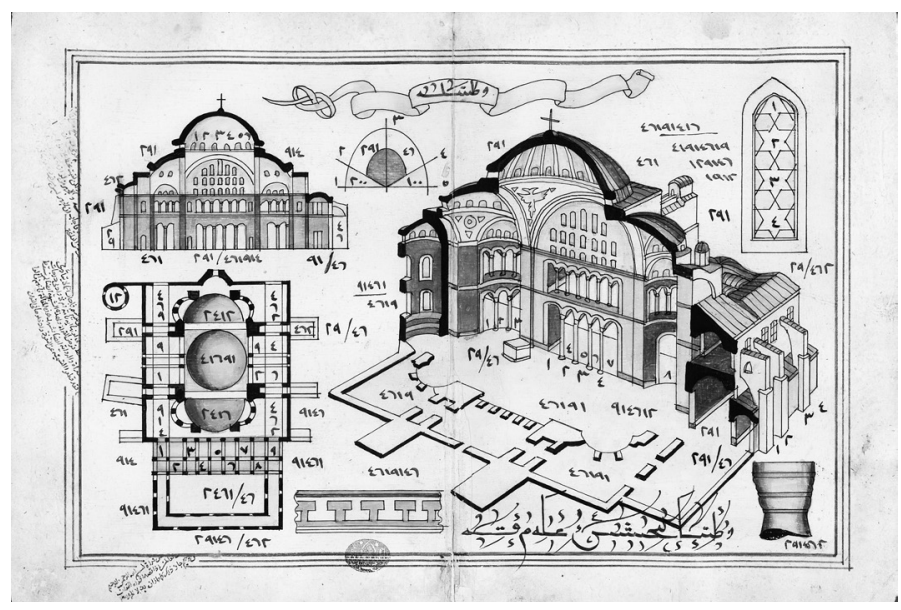

Fig. 1. The hand drawing on paper of Hagia Sophia at Constantinople. Date unknown. 
way to protect the author's name. If so, the Koranic comments were possibly added to the drawings at a later time. The second possibility is related to an Islamic author, who would certainly not be averse to presenting the Islamic alterations to the building or Islamic religious symbols, but only if the drawings were made after the Hagia Sophia was transformed into a mosque. As it is, there is a possibility that the document was made before the Turkish conquest, but also represented the divine dignity of the church and respect for the magnificent importance it held for Muslims in the centuries before the conquest, as Necipoglu documented. ${ }^{2}$ That would explain the Koranic comments, in which the structure of the building seems to be equated with the text of theological importance. By this, it is similar to the Islamic presentation named Djawal, which consists on geometric patterns or a plan with numerical alterations, surrounded by the Koranic verses. ${ }^{3}$ However, we should keep in mind that alteration of Koranic verses to an important discussion, literal or pictorial, is a broad tradition in Islamic culture.

It seems that one detail can help in the possible clarification of some issues here discussed. The representation in the library seal, pressed on the lower horizontal margin, contains an image of a dome built of stone blocks, with minarets on both sides. A star is placed on each side, between the dome and the minarets (Figure 2). There is a strong similarity in character of image, shape of dome, and presented technique of its construction between the representation on the seal and of those found in the medieval Shiite pilgrimage scroll, related to the shrine of imam Husayn at Karbala. ${ }^{4}$ Despite its importance, this similarity cannot indicate the exact origin or the author of the representation, nor the time of its appearance (Figure 3). However, the possibility that this presentation of Hagia Sophia was part of an Islamic library or school indicates its own importance and a likelihood that it is a copy of an older document made by an Islamic author.

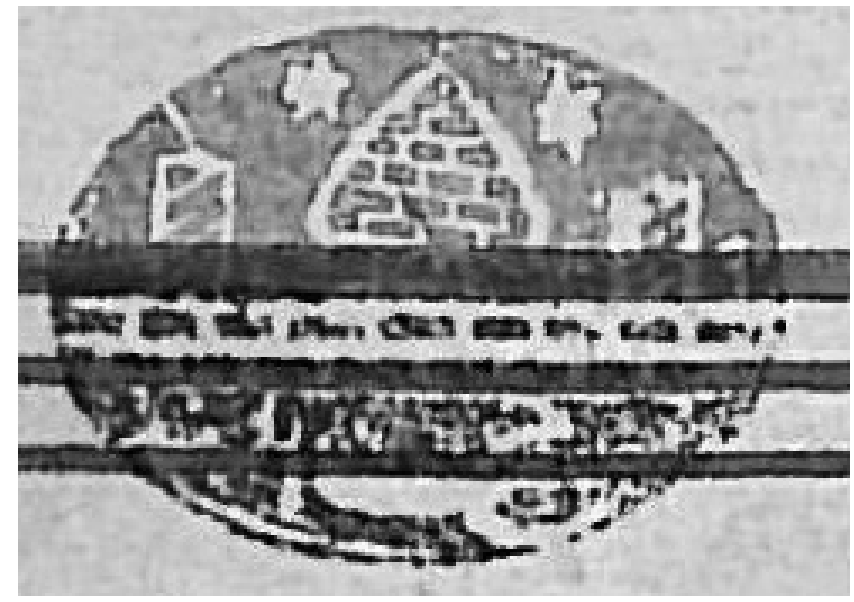

The seal applied to the lower margin of the document. Fig. 2 . 
The analysis of the numerical system used in the document and its relation to the drawings indicates two kinds of use of numbers. The first one serves to show the number of windows in the dome, presented in the section of the building, the number of arches related to the central section of the church, and the number of flying buttresses placed on the west façade, in the axonometric drawing, as well as the number of vaults over the parvis presented in the plan.

However, the second numerical system seems to be based on a philosophical approach to the ideal meaning of the interpretation of the church of Hagia Sophia. We are driven to this conclusion not only by the particular character of the numerical system related to the parts of the architectural structure, but also by the position of the plan according to the section. The plan is not positioned to correlate architecturally to the section, which indicates that we are not looking at a professional architectural plan, but a polygon for expressing particular numerical meanings.

There are only five numbers used in this system: $1,2,4,6$, and 9 . It is interesting that when they compose a compound number, they are not added one to another to give a sum of the used numbers, but are altered to produce a raw, e.g. 41691 or 914612. There is a strong sense that by these means these five numbers express a kind of process, related to a particular meaning of the architecture and its significance as a creation. Further, it is important to emphasize that the possible system of expressing such ideas comes as an interpretation of a building erected long time prior. This fact raises the possibility that the author of this document used the building of Hagia Sophia to interpret universal symbolical values related to the process of creation in general. In this way, he is also magnifying the importance of this architecture to the level of universal harmonic order, which was not unusual in the Islamic cultural and philosophical tradition. ${ }^{5}$

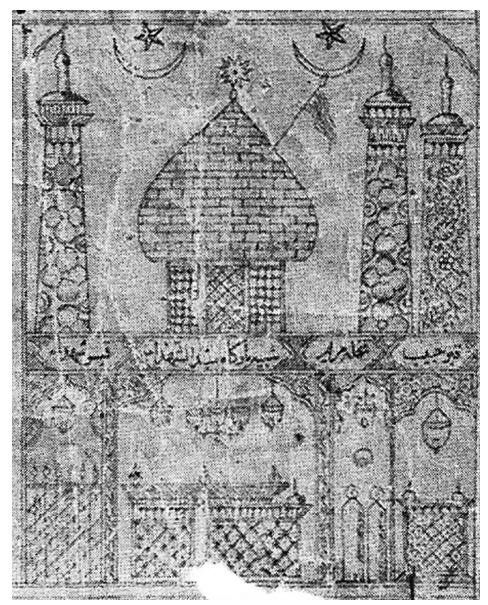

Fig. 3. Image from a mediaeval Shiite pilgrimage scroll, related to the shrine of imam Husayn at Karbala. 
The possibility that this numerical system was used for such a purpose indicates the way in which these five numbers appeared in the document in first place. They are presented as a progression in the upper left corner of the plan. Numbers 1 and 2 are placed together in the circle of the skeuophylakion, following the horizontal line. They are accompanied by 4,6 , and 9, placed within the left upper corner of the square which forms the naos of the church, but following the vertical line. In the same way, these five numbers appear in Nicomachus, when presenting the geometric progression: 1, 2, and 4 in a horizontal raw, and 4,6 , and 9 in the vertical raw, where number 4 belongs to both lines of number progression. ${ }^{6}$ Number 4 relates to 2 as 2 to 1 , giving the ratio $1: 2$; and on the other side, 4 relates to 6 as 6 to 9 , giving the ratio 2:3. Although the interest of Islamic philosophers in ancient arithmetic, particularly of Nicomachus and Neo-Pythagorean, is well known and carefully documented, ${ }^{7}$ it is important for our discussion to emphasize the part of the Epistle on Arithmetic written by the Brethren of Purity. ${ }^{8}$ In the chapter 22, they emphasize the use of numbers 2, 4, 6 , and 9 , and their ratios, forming the geometric progression, where the number 1 is representing the monad, the beginning and the sum of all numbers. By this, the numerical system in our document finds its support in one of the most important Islamic philosophical text on arithmetic.

However, it seems that the use of these five numbers is not only the consequence of their mathematical significance. The compound numbers formed by 1, 2, 4, 6 , and 9, indicate the possibility that their symbolical meaning has also been taken into account. No rational mathematical logic can be grasped from the way in which they alter from one to another, rather it seems that they follow a particular connection to the architectural structure, and to the cardinal directions of east and west. Compound numbers seems to follow a particular metaphorical logic, usually emphasized as the essence of aesthetic and spiritual appreciation of the universe, and architecture as its material image. This appreciation is based on the inside capacities of the soul and its ability to comprehend the relationship between immaterial essence of its material reflection. ${ }^{9}$

In the Islamic tradition, number 1 represents the Creator, One, primordial existence of the Monad, the beginning and the sum of all other numbers and principles. Number 2 identifies the Intellect, the active principle of creative power. Number 4 is the matter of artifacts, material order, the square. Number 6 is the first body consisting of six directions, the cube, and ideal form. Number 9 is the "sphere of spheres", the final number of the cycle and the symbolical end of all numbers, the sum of all beings in existence, their completion and fulfillment. ${ }^{10}$ Even in the western Middle Ages we encounter the strong influence 
of Islamic symbolical appreciation of the number nine. Magister Johannes in his adaptation of the lost Arabic work of Muhammad ibn Musa al-Khwarismi states that "the nine is the first number to contain a perfect number, a cubic number, and a plane number'. ${ }^{11}$

However, the symbolical use of five named numbers in discussion, it seems to correlate also with Islamic philosophical ideas, particularly with the description of five eternal principles of the universe, explained by Muhammed ibn Zakariya al-Razi at the end of the ninth century. In his text we read that the first eternal principle is God and his wisdom which is perfect and pure intelligence; the second is the soul inclining to produce material forms in this world; the third eternal principle is matter; the fourth is the space; and the fifth is time, which is also movement, usually circular according to the ideas of Plato. ${ }^{12}$ It seems that the symbolical meanings of the numbers 1, 2, 4, 6, and 9 correlate essentially with this explanation of eternal principles. By this we can reach the broader meaning of the particular relationship which was developed between architectural representation of Hagia Sophia as a model of universal creativity, and the numerical system used to explain its essential meaning.

In the further discussion, we will use these symbolical meanings related to each of the numbers in order to comprehend their compound forms and their relation to the architectural structure of Hagia Sophia.

As a first step in the process of clarification of the possible meaning of the used numerical system and its symbolism, we should pay attention to the representation of the sphere, placed between the axonometric drawing and the section of the building. The drawing shows one half of two concentric ellipses, further differentiated by color, where the larger, external one, is divided into five parts by a vertical and two lateral lines producing acute angels. The point of their intersection with the external ellipse is marked as 1,2,3,4, and 5. The smaller ellipse ends at the lines producing the acute angels. What is important for our analysis is the appearance of compound number 291 in the upper left section of the ellipses and 46 in the upper right section. Inside the angles, on the left side, we read the number 200, and 100 on the right. These numbers, used only in the context of this drawing, also have a symbolic significance. The number 100 signifies the assembly of all things in the plan of the Creator, while the number 200 indicates the return of all things to the One, which is their principle and entelechy. ${ }^{13}$ 
Following the possible logic of the alteration of symbolic meanings of presented numbers, on the left side we can read that by the potentials of the active creative power (number 2) and by reaching the completion of the creative process (number 9), both merging and finishing in the absolute One (number 1), all created things return to that One (number 200). On the right side we grasp that this process can be conducted by way of originating from the order of matter (number 4) and by achieving its perfect bodily appearance (number 6), according to the laws by which all the things are assembled in the plan of the Creator (number 100). Inscribed in the shape of an elliptic sphere, the number meanings established this way correspond perfectly to a universal idea of harmony, correlating invisible potentials and visible means of the creative powers of the cosmos. The geometric counterpart to the presented numbers perfectly reflect the ideas expressed in the Islamic philosophical tradition, where the circular or spherical form of the cosmos indicates the return of the created world into the perfect realm of the Creator, while the sphere was the first and perfect manifestation of the created universe. ${ }^{14}$ In this context the image of the sphere, which consists of two concentric ellipses (the larger one probably representing the heavenly realm, maybe even air or water, and the smaller the sphere of Earth) can be thought as the geometric pattern of the universal harmony between the elements structuring the world.

In support of this idea, we should mention that in Islamic mystical doctrines, numbers 100 and 200, have additional meanings, related to the name of Allah, and the categories reflecting, among other, the elements of the world structure. In the practice of $\mathrm{Da}$ 'Wah (call), developed by sheik Abu'b - Muwwayd, we read the number 100 as Qadir, one of the names of Allah, to which belongs the element of water, and the number 200 as Rabb, connected to the element of earth. ${ }^{15}$ It seems that this kind of meaning fits into the idea of the sphere representation of the world, consisting on natural elements as earth, air, and water. Reflecting closer to this idea, in the Epistle of music of the Ikhwan Al-Safa, we read not only that the sphere of air can be identified with the number 9, but also that the harmony of the universe rests particularly in the relationship between spheres of earth and air. ${ }^{16}$ In this context, we can also reflect on a few literary expressions related to architecture and creative powers which are forming it. When in the preface of Tezkiretu'l - Bunyan, we read of the heavenly metaphors related to architecture, and how it was accomplished through the workshop of water and earth, then the context of our example finds its support in Islamic interpretations of the symbolical meaning of architecture. ${ }^{17}$ In other ideas, for instance in the thirteenth century philosopher ibn Taimiyya, the celestial sphere 'arsh, which 
is the highest of all heavens above the earth, is identified with the shape of dome - qubbba. ${ }^{18}$ However, it seems that in the Islamic philosophical tradition a comparison between the heavenly sphere and its architectural representation, can occur even more sophisticated, by gradation of correlated notions: the idea of the heist haven is related to the sphere as its geometric expression, and both of them to the dome as their materialized symbolical form. It reflects on the profound differentiation of the logical, numerical, and visible material existence correlated to the power of intellect.

When applied to the drawing of the building's section, the similarity of the analyzed representation and the spherical shape of the dome and the arches on the wall of the naos come into focus (Figure 4). The lower zone of the wall, colored darker, seems to correspond to the aspects symbolically expressed by the numbers 100 and 200. If we draw over the section, the system of lines represented in the image of the sphere, a vertical axis and two lateral lines producing the same acute angles, will create perfect overlap. The intersecting points of the lateral lines with the section of the building will mark the horizontal line which divides the lower, earthly part, from the upper zone of arches, vaults, and dome, as the representation of the heavenly sphere. For this discussion is important to be emphasized that a similar geometric structuration of the sphere of dome can be seen in so called Chahar Taq (Figure 5), a particular Islamic architectural practice.$^{19}$ It shows that the author of our document probably used, for him recognizable widely circulated construction pattern, to explain the existing dome of Hagia Sophia by the most sophisticated geometric principles of Islamic architecture.

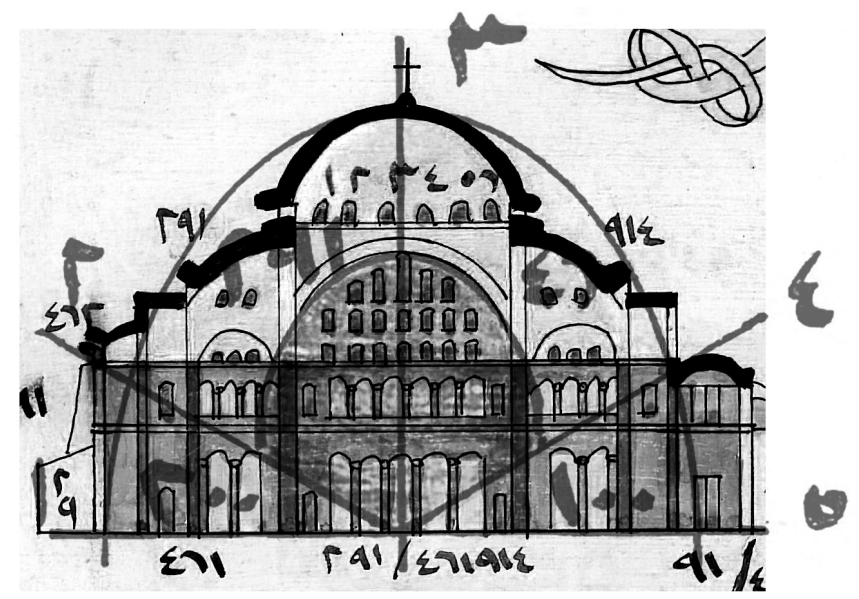

Fig. 4. Compositional relation between the depicted section of the church and the sphere. 
Moreover, the compound numbers related to the upper zone: 291, 462, 914, correspond in a developed manner to the basic idea of potentials and means of the creative process exposed in the image of the sphere. The compound number 291, placed on the left side of the dome, can be interpreted as the beginning of the creative activity (number 2 ) and the condition for the accomplishment of the creation and the return of all things to One (number 91). There can also be an alternate reading that indicates the accomplishing of the half sphere, where number 2 stands in relation to number 4 as half of a geometric image. By the same logic, the number 914, placed on the right side of the dome, indicates that the accomplishment of the creative process leads through the material order (number 4), from which all other aspects of the visible world originate. Actually, it indicates that the complete sphere (number 91) can be shaped through the square, as the perfect image of material order (number 4). It is important to emphasize that in the Islamic cosmology, the highest sphere is the ninth one called talak-al-aflak, the sphere of spheres, and in the context of our example it carries an important meaning. ${ }^{20}$ In the same manner, the number 462 indicates the means by which the creative power builds up the visible world, the material order, and three dimensional body (numbers 4 and 6), initiated by the Intellect (number 2). When after the compound number 46 the numerical suffix is 1 , this is an indication that the process of finalizing the cube through the square is completed. It seems that the last number in these examples indicates the nature or the stage of the creative process (its accomplishment by 1 , active initiative by 2 , or the stage of material ordering by 4 and 6 ).

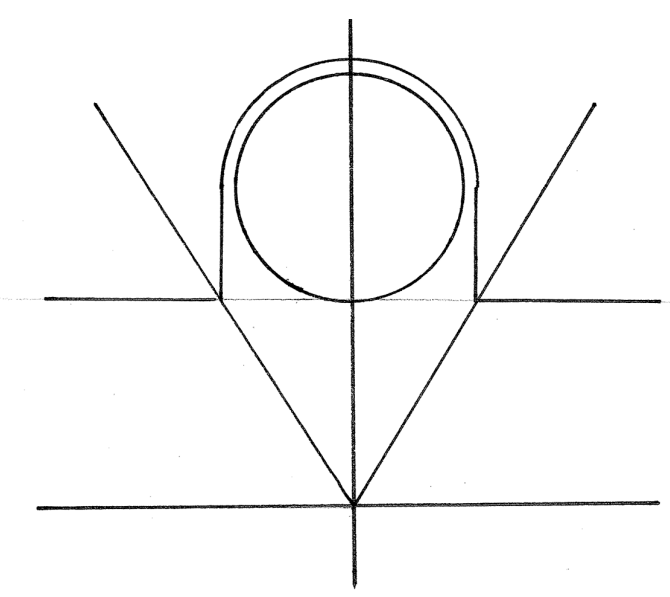


In this context, the appearance of numbers 2 and 9 , inscribed near the apse, and numbers 4 and 6 , marking the position of the main entrance into the building, placed in the lower zone, seems to be related to the idea of pure creative potential, as the beginning and the end of the process (numbers 2 and 9), and to the expression of pure means by which the creative power operates in the visible world, the material order, and the three dimensional body (numbers 4 and 6). There is a possibility that even the position of these numbers has been symbolically related to cardinal directions: 2 and 9 in the east, and 4 and 6 in the west, marking the daily motion of the sun. The idea of the whole process of creation is reflected in the ratio $91 / 46$, inscribed in the lower right part under the section. It is a reminder that the completeness of creation (number 91) is proportionate to the use of creative means (number 46). In that sense, the ratio inscribed in the middle, under the section drawing, 291/461914, refers to the creative process as the whole, where the active Intellect at the beginning and the completeness of the creation at the end (number 291) is proportionate to the idea that through the initiative of the use of the material order (the first number 4), and thereby the final shaping of the three dimensional body (number 61 ) under the final structuring of the sphere (number 91), presents the material order by itself as condition of the creative power (the last number 4).

This example indicates that the process of deciphering the larger compound numbers is highly complex, because there is a greater possibility of more uncertain interpretations. However, the number placed in the main dome, presented in the plan of Hagia Sophia, seems to provide an opportunity for an attempt at a more accurate result. The compound number 41691, related to the main dome, in the context of the proposed system of reading of the numerical meaning, can be interpreted as: when the material order has been completed (number 41), through the three dimensional body which is the cube (number 6 ), the creation of the whole and the return of all beings into One has been completed through the image of the sphere (number 91). The variable of the last interpretation joins 6 and 91, and can be read as: through the accomplishment of the three dimensional body under the sphere as the image of the visible universe, all creation returns to One.

According to the logic of this numerical reading, probably all other compound numbers and their ratios can be deciphered, although the reading of large compound numbers often remains in the domain of an obscure dissertation. However, what is clearly discernible is the intention of the author to express the idea of the completeness of universal creative power through the symbolic 
numerical system related to the architectural structure. In particular because the pictorial representation of the architectural structure of Hagia Sophia is composed as a complete and perfect whole. The drawings of the decorative parts and the window, harmoniously composed among the main presentation of the building structure, are reflected in this aesthetic position, exposed in the Islamic tradition. We should remind on the Islamic philosophical ideas by which the presence of ornamentation indicates the existence of the absolute order by executing the complete and perfect sensation that an architectural body can offer, equally in its material and symbolical appearance. It also reflects on the perfection of the universe. ${ }^{21}$ And again, through the text of Risale-I Mi'maryye, we can read on what consists the idea of wonderful creation through architectural metaphors. It is talking that through vault, lamp ornament, bright window, luminous tapers, beauteous form, lofty arch and the great pavilion, and at the end, the vault of heaven and the surface of the world, we can reach the comprehension of perfect harmony. ${ }^{22}$ The presented decorative parts correspond to the idea of completeness, with the window as presence of divine light.

After discussed issues reflecting on the numerical representation of Hagia Sophia at Constantinople, there remains a particular question regarding its purpose. Was it a part of a larger, extensive exposition on the importance of the building, or just a scholarly exercise showing and teaching the essential connection between architecture and arithmetic, manifesting their universal importance, or both combined? Whatever the exact purpose of this representation was, the author proves himself as educated in important philosophical issues, particularly in the doctrine of Ikhwan Al-Safa, and in Neo-Platonic aspects of the science of arithmetic and geometry. For instance, it seems that there is a strong similarity between the previously explained disposition of numbers and their meanings in the discussed document, with the part of Ikhwan Al-Safa's doctrine regarding the notion of cosmic creative power and its active appearance in this world. This power appeared in the process of metaphysical transformation of substance into form and matter, reflecting on the Neo-platonic cosmic hierarchy embodied in cosmic positions, not only of the named constituencies, but also on their imagined various stages of inter relationships composing the universal order. As Fackenheim emphasized, the Brethren of Purity 'worked out detailed and continuous system of levels as possible, using the Neo-platonic principle of gradually increasing multiplicity emanating from the One. Using numbers and mathematics in a fashion which in its detailed character appears almost absurd, they relate increasing multiplicity and decreasing perfection to the distance from God'. ${ }^{23}$ 
In comparison to other older pictorial representations of Hagia Sophia, the discussed drawings occur to be highly accurate in depicting the structure of the building. It seems that the author of these drawings understood perfectly the logic of architectural representation, despite the fact that the plan and the section of the building do not correspond architectonically. For now, according to our knowledge, there is one representation of Hagia Sophia similar by a few elements to this one. In 2016 it was sold at the Roseberys auction, London, as a page from a Nord Indian illuminated manuscript from the eighteenth century. The drawing shows section and the plan of the building, architecturally correlated and even more accurate in details than in discussed document. However, the representation is surrounded by a text generally describing the structure of the building, with just a few numbers related to the drawings. For instance, number 412 marks the dome, and 419 and 419-1 the half domes. There is also use of numbers 3 and 5 , but the whole applied numerical system is not developed systematically as in our document, and it is not representing the exclusive way of interpreting the structure of the building. However, there is a possibility that these two examples are linked, particularly because in the Indian example the structure of Hagia Sophia is also presented without Islamic alterations, although there is the crescent moon placed over the dome in the section. These elements are strengthening the feeling that there was a broader use of such interpretations in pre modern Islamic culture.

However, it is from a crucial importance to emphasize that the nature of representation discussed in this work is, by the logic and essential understanding what makes the magnificent importance of the building of Hagia Sophia, very close to literary texts appreciating its exceptional value. For instance, in the description given by Cefer Celebi, which fallows the great Byzantine tradition, the metaphorical reconstruction of the cosmic structure captured in the building was exposed. ${ }^{24}$ In our document we read almost the same significant aspects but expressed through the symbolical numerical essence of such structure, and the universal creative power behind it. It seems that there is a strong principle connection between the textually exposed metaphorical and numerical meaning. However, the applied numerical system is closer to the idea of the building as the imago mundi, and to the notion of creation as the proportional hierarchy of numbers and their meanings. By this, discussed numerical expression of the Hagia Sophia, was translated from its material structure into pure spiritual context of the cosmic structure, reaching the higher level of a perfect cognitive meaning. 

(Unpublished PhD. Dissertation, Adelaide: University of Adelaide, 2006), 229.

Gurlu Necipoglu, "The Life of an Imperial Monument: Hagia Sophia after Byzantium," in Hagia Sophia from the Age of Justinian to the Present (London: Cambridge University Press, 1992), 195225. Jean Chevalier, Alain Gheerbrant, The Penguin Dictionary of Symbols (London: Penguin Books). Ulrich Marzolph, "From Mecca to Mashhad: The Narrative of an Illustrated Shiite Pilgrimage Scroll from the Qajar Period,” Shangri La Working Papers in Islamic Art, no.5, (July 2013), Fig.21,22. Hooman Koliji, In Between: Architectural Drawing and Imaginative Knowledge in Islamic and Western Traditions (London: Routledge, 2016), 56-58. Nicomachus of Gerasa, Introduction to Arithmetic (Great Books of the Western World, Encyclopedia Britannica: William Benton Publisher, 1980), 830, 844. 
Alfred Ivry,"The Utilization of Allegory in Islamic Philosophy,“ in Interpretation \& Allegory: Antiquity to the Modern Period (Boston: Brill Academic Publishers, 2003), 166; Gulru Necipoglu, "The Scrutinizing Gaze in the Aesthetics of Islamic Visual Cultures," Mudarnas, Annual of the Visual Cultures of the Islamic World, 32, (2015): 29-33; Morkos, "A Study of Ottoman Narratives on Architecture," 243, 272-276.

Seyyed Hossein, An Introduction to Islamic Cosmological Doctrines, 51-52,78,82-84; Annemarie Schimmel, The Mystery of Numbers (Oxford: Oxford University Press, 1993), 41,48,86,122,167.

Kurt Lampe, "A Twelfth-Century Text on the Number Nine and Divine Creation: A new Interpretation of Boethian Cosmology?,“ Mediaeval Studies, vol.67 (2005): 8.

A History of Muslim Philosophy, Sharif M.M., Otto Harrassawits eds. (Wiesbaden: 1963), vol.I, ch.22.

Seyyed Hossein, An Introduction to Islamic Cosmological Doctrines, 237.

Samer Akkach, Cosmology and Architecture in Premodern Islam (Albany: State University of New York Press, 2005), 72,125.

Chevalier, Gheerbrant, The Penguin Dictionary of Symbols.

Seyyed Hossein Nasr, The Sense of Unity: The Sufi Tradition in Persian Architecture (Chicago: University of Chicago Press, 1973), 75.

Akkach, Cosmology and Architecture in Premodern Islam, 52.

Emil Fackenheim, "The Conception of Substance in the Philosophy of the Ikhwan Al-Safa," Mediaeval Studies, vol.5 (Toronto: 1943): 119. 
Akkach, Samer. "Analogy and Symbolism: an Approach to the Study of Traditional Islamic Architecture." The Islamic Quaterly 36(2): 1992.

Akkach, Samer. Cosmology and Architecture in Premodern Islam. Albany: State University of New York Press, 2005.

Brethren of Purity. On Arithmetic and Geometry. Oxford: Oxford University Press, 2012.

Chevalier, Jean and Gheerbrant, Alain. The Penguin Dictionary of Symbols. London: Penguin Books.

Fackenheim, Emil. "The Conception of Substance in the Philosophy of the Ikhwan Al-Safa." Mediaeval Studies, vol.5. (1943).

Ikhwan Al-Safa. The Epistle on Music. Tel Aviv: Tel Aviv University, 1978.

Ivry, Alfred. "The Utilization of Allegory in Islamic Philosophy." In Interpretation and Allegory: Antiquity to the Modern Period. Boston: Brill Academic Publishers Inc., 2003.

Koliji, Hooman. In Between: Architectural Drawing and Imaginative Knowledge in Islamic and Western Traditions. London: Routledge, 2016.

Lampe, Kurt. "A Twelfth - Century Text on the Number Nine and Divine Creation: A New Interpretation of Boetian Cosmology? “ Mediaeval Studies, vol.67 (2005).

Morkoc, Selen. A Study of Ottoman Narratives on Architecture: Text, Context and Hermeneutics. unpublished PhD Dissertation. Adelaide: University of Adelaide, 2006.

Nasr, Seyyed Hossein. The Sense of Unity: The Sufi Tradition in Persian Architecture. Chicago: University of Chicago Press, 1973

Nasr, Seyyed Hossein. An Introduction to Islamic Cosmological Doctrines. Albany: State University of New York Press, 1993.

Necipoglu, Gulru. "The Life of an Imperial Monument: Hagia Sophia after Byzantium.“ In Hagia Sophia from the Age of Justinian to the Present. London: Cambridge University Press, 1992.

Necipoglu, Gulru. "The Scrutinizing Gaze in the Aesthetics of Islamic Visual Cultures." In "Gazing Otherwise. Modalities of Seeing in and Beyond the Lands of Islam", in Mudarnas, Annual of the Visual Cultures of the Islamic World (32), 2015.

Nicomachus of Gerasa. Introduction to Arithmetic. Great Books of the Western World, Encyclopedia Britannica. London: William Benton Publisher, 1980.

Schimmel, Annemarie. The Mystery of Numbers. Oxford: Oxford University Press, 1993.

Sharif, M.M., and Harrassawits, Otto. A History of Muslim Philosophy. Wiesbaden: 1963. 
Cilj moje diskusije je da istaknem karakter moderne i savremene estetike u odnosu na teoriju umetnosti, kroz dijagramsku refleksiju o binarnosti, razlikama i rekonstrukcijama dijalektike.

KLJUČNE REČI: UMENTIČKE ŠKOLE, MARKSIZAM, KRITIČKA TEORIJA, ANALITIČKA ESTETIKA, ISTORIJA UMETNOSTI, FENOMENOLOGIJA, STRUKTURALIZAM, POSTSTRUKTURALIZAM, SAVREMENA ESTETIKA I UMETNOST

\section{JEDNO ISLAMSKO NUMERIČKO TUMAČENJE SVETE SOFIJE U CARIGRADU}

\section{Vladimir Mako}

Ideje koje se odnose na estetičko mišljenje o arhitekturi tokom istorije su razvile brojna tumačenja o kulturnom i društvenom značaju građevina. Ova tumačenja su često oblikovana kao svet mogućeg postojanja posebnih značenja struktuiranih snagom čovekove imaginacije kojom dosežu nesvakidašnje nivoe kreativnog saznanja o tome šta arhitektura može suštinski odražavati.

U tom smislu rad istražuje jedan takav mogući svet značenja, predstavljenog u obliku numeričkog tumačenja arhitektonske strukture Svete Sofije u Carigradu. Pored svoje složene i hermenautičke prirode, analizirani dokument otkriva visoko prefinjeni nivo međuodnosa različitih kulturnih elemenata. Oni su povezani u celinu čija idealistička i poetska priroda, čini se da je zasnovana na kosmopolitanskom pristupu filozofiji, religiji, kao i ljudskoj sposobnosti razumevanja božanske suštine kreativnosti.

KLJUČNE REČI: ARHITEKTURA, ESTETIKA, BROJ, ISLAMSKA FILOZOFIJA, KOSMIČKA STRUKTURA

\section{MEDJUNARODNA ESTETIKA I KONGRESI NA TU TEMU}

\section{Aleš Erjavec}

Poslednjih decenija međunarodni kongresi na temu estetike su bili i ostaju najvidljiviji i najuticajniji estetski skupovi u svetu. Na tim kongresima učesnici jačaju svoju identifikaciju sa estetikom i istovremeno se odvajaju od nje: pokrivaju široku i nedefinisanu teritoriju zvanu "teorija". Održavajući se na različitim geografskim, a time i specifičnim kulturno-istorijskim lokalitetima, kongresi na temu estetike ne samo da okupljaju strane učesnike, već dovode i domaću publiku u kontakt sa globalnim autorima, temama, problemima i metodama. Teme, pitanja i metode se posmatraju kroz umetnost i filozofiju i pomažu da estetika postane relevantna teorijska aktivnost. To važi za neke zapažene nedavne događaje: uspon i pad postmodernizma; reintegracija bivše istočne Evrope u globalnu kulturu; i slična, ali takođe duboko drugačija transformacija estetike u Kini, gde je intenzivno prisutan novi preporod estetike, često sa kineskim bojama. To su, rekao bih, tri istorijska dogadjaja koja su se pojavila u estetici tokom poslednje tri decenije. Oni su i danas prisutni i tako ostaju presudni za razumevanje naše stvarnosti. Postoje i izuzeci koji dokazuju da su nove filozofske teorije estetike danas retke, ali nisu nemoguće; kao na primer teorija Žaka Ransijera. Ovo će biti neka od glavnih pitanja kojima će se baviti ovaj rad.

KLJUČNE REČI: MEDJUNARODNA ESTETIKA, MEDJUNARODNI KONGRESI O ESTETICI, TRANSFORMACIJA ESTETIKE, ŽAK RANSIJER, TEORIJE ESTETIKE 